\title{
Anesthetic considerations in a patient with visceral leishmaniasis
}

\author{
[Éléments de l'anesthésie d'un patient atteint de leishmaniose viscérale]
}

\author{
Prakash K. Dubey MD, * Prabhat K. Sinha MD, $†$ Kumar H. Raghwendra MD *
}

Purpose: To describe the anesthetic problems in a patient with visceral leishmaniasis undergoing general anesthesia.

Clinical features: A 17-yr-old man with visceral leishmaniasis was booked for emergency appendectomy. He received parentral sodium stibogluconate $600 \mathrm{mg}$ per day. The patient was pale, afebrile and had hepatosplenomegaly. Preoperative investigations showed a hemoglobin of $6.2 \mathrm{~g} \cdot \mathrm{dL}^{-1}$, platelet count of $80 \times 10^{9} \cdot \mathrm{L}^{-1}$ and serum albumin of $2.1 \mathrm{~g} \cdot \mathrm{dL}^{-1}$. The electrocardiogram and chest $x$-ray were normal. Anesthesia was induced with $100 \mu \mathrm{g}$ fentanyl and $50 \mathrm{mg}$ propofol iv and tracheal intubation was facilitated with $3 \mathrm{mg}$ vecuronium iv. Maintenance of anesthesia was done with intermittent positive pressure ventilation using $50 \%$ nitrous oxide and $0.4 \%$ isoflurane in oxygen. Reversal of neuromuscular blockade was achieved with $1.0 \mathrm{mg}$ neostigmine and $0.2 \mathrm{mg}$ atropine iv. $50 \mathrm{mg}$ tramadol iv every six hours was used for postoperative analgesia. The perioperative course was uneventful.

Conclusion: Patients with visceral leishmaniasis have problems unique to them that may influence the anesthetic management. Of particular concern to an anesthesiologist are the presence of hematological abnormalities (anemia, leukopenia, thrombocytopenia), and hypoalbuminic malnutrition. The combination of low hemoglobin and thrombocytopenia may necessitate blood component therapy perioperatively. Drugs affecting coagulation should be used judiciously. Hypoalbuminemia may adversely affect the pharmacokinetics of agents that are highly protein bound. The anesthetic management in a patient with visceral leishmaniasis may be further complicated by the presence of coexisting infections like pneumonia and tuberculosis. Leishmaniasis is a recognized complication of infection with human immunodeficiency virus.
Objectif : Décrire les difficultés anesthésiques qui se sont présentées lors de l'anesthésie générale d'un patient atteint de leishmaniose viscérale.

Éléments cliniques : Un homme de 17 ans, atteint de leishmaniose viscérale, a été admis pour une appendicectomie d'urgence. II a reçu une injection parentérale de $600 \mathrm{mg}$ par jour de stibogluconate de sodium. Le patient était pâle, afébrile et présentait une hépatosplénomégalie. Les examens préopératoires ont montré une hémoglobine de $6,2 \mathrm{~g} \cdot \mathrm{dL}^{-1}$, une numération plaquettaire de $80 \mathrm{x}$ $10^{9} \cdot \mathrm{L}^{-1}$ et une albumine sérique de $2,1 \mathrm{~g} \cdot \mathrm{dL}^{-1}$. L'électrocardiogramme et la radiographie pulmonaire étaient normaux. L'anesthésie a été induite avec $100 \mathrm{mg}$ de fentanyl et $50 \mathrm{mg}$ de propofol iv et l'intubation endotrachéale a été facilité par l'injection iv de $3 \mathrm{mg}$ de vécuronium. L'anesthésie a été entretenue avec une ventilation à pression positive intermittente en utilisant $50 \%$ de protoxyde d'azote et 0,4 \% d'isoflurane dans de l'oxygène. La décurarisation a été réalisée avec l,0 mg de néostigmine et 0,2 mg d'atropine iv. L'analgésie postopératoire a été assurée par du tramadol iv administré toutes les six heures. L'opération s'est bien déroulée.

Conclusion : La leishmaniose viscérale présente des problèmes uniques qui peuvent influencer la démarche anesthésique. L'anesthésiologiste se soucie particulièrement de la présence d'anomalies hématologiques (anémie, leucopénie, thrombocytopénie) et de malnutrition avec hypoalbuminémie. La combinaison d'une faible hémoglobine et de thrombocytopénie peut nécessiter la transfusion périopératoire de composants sanguins. On doit utiliser judicieusement les médicaments qui affectent la coagulation. L'hypoalbuminémie peut agir défavorablement sur la pharmacocinétique de médicaments au lien protéinique marqué. La démarche anesthésique à adopter chez un patient atteint de leishmaniose viscérale pourrait se compliquer davantage par la présence d'infections coexistantes comme la pneumonie et la tuberculose. La leishmaniose est une complication reconnue chez les porteurs du virus de l'immunodéficience humaine.

From the Department of Anesthesiology and Critical Care Medicine, ${ }^{*}$ Indira Gandhi Institute of Medical Sciences, Patna and the Government Medical College, $†$ Chandigarh, India.

Address correspondence to: Dr. Prakash K. Dubey, 305, Janpriya Apartments, North S.K.Puri, Patna 800 013, India.

E-mail: pkdubey@hotmail.com

Accepted for publication October 17, 2000

Revision accepted February 12, 2001. 


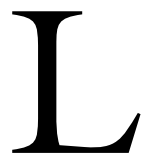

EISHMANIASIS is the term that refers to several clinical syndromes caused by obligate intracellular protozoa of the genus Leishmania. In humans, the disease is visceral, cutaneous or mucosal resulting from infection of macrophages throughout the mononuclear-phagocyte system, in the skin and in the nasopharyngeal mucosae, respectively. ${ }^{1}$ Visceral leishmaniasis occurs widely throughout the world, i.e., South America, South Africa, the Mediterranean countries, India, Bangladesh and China. ${ }^{2}$ The population at risk is about 350 million and the incidence per year is 1.8 million new cases. ${ }^{2}$ The Ganges and Brahmaputra River valleys of the Indian subcontinent are the home of epidemic visceral leishmaniasis, or kala-azar. Kalaazar means black sickness and visceral leishmaniasis in India is characterized by hyperpigmentation of the face, hands, feet and abdomen. The causative leishmanial species can be transmitted by sandflies, congenitally and parenterally (e.g., via blood transfusion and sharing of needles). ${ }^{1}$ Europeans and Americans acquire the disease while visiting an endemic area.

There is a worldwide increase in the number of cases and a more widespread geographical distribution is emerging. However, there are no reports of problems in anesthetic management of patients with leishmaniasis. We report a patient with visceral leishmaniasis who had emergent appendectomy.

\section{Case report}

A 17-yr-old man, weighing $32 \mathrm{~kg}$, was booked for appendectomy. He was a known case of visceral leishmaniasis (kala-azar) and was being treated with parenteral sodium stibogluconate $600 \mathrm{mg}$ daily for the last five days. The patient was afebrile and physical examination revealed marked pallor, an enlarged spleen reaching down to the umbilicus and a mildly enlarged liver. The cardiovascular and respiratory systems were normal. Blood examination revealed a hemoglobin of $6.2 \mathrm{~g} \cdot \mathrm{dL}^{-1}$, platelet count of $80 \mathrm{x}$ $10^{9} \cdot \mathrm{L}^{-1}$, serum albumin concentration of $2.1 \mathrm{~g} \cdot \mathrm{dL}^{-1}$ and serum globulin concentration of $7.2 \mathrm{~g} \cdot \mathrm{dL}^{-1}$. The rest of the hematological tests, liver and renal function tests were within normal limits and the electrocardiogram and chest $x$-ray did not show any abnormality. The patient was seronegative for human immunodeficiency virus (HIV).

Intraoperative monitoring included continuous lead II ECG, pulse oximeter, non-invasive blood pressure and capnograph. Anesthesia was induced with $100 \mu \mathrm{g}$ fentanyl and $50 \mathrm{mg}$ propofol $i v$ and tracheal intubation was facilitated with $3 \mathrm{mg}$ vecuronium $i v$. Anesthesia was maintained with $50 \%$ nitrous oxide and
$0.4 \%$ isoflurane in oxygen, intermittent positive pressure ventilation and incremental doses of vecuronium. At the end of the procedure neuromuscular blockade was reversed with $1.0 \mathrm{mg}$ neostigmine and $0.2 \mathrm{mg}$ glycopyrrolate $i v$ and the trachea was extubated without complication. The anesthetic course was uneventful and the patient remained hemodynamically stable throughout. Tramadol, $50 \mathrm{mg}$ iv every six hours was used for providing adequate postoperative analgesia. The postoperative course was uneventful and parenteral sodium stibogluconate was continued throughout his hospital stay. Two units of fresh whole blood were transfused postoperatively. The patient was discharged on the seventh postoperative day.

\section{Discussion}

Leishmaniasis in man may be cutaneous, mucocutaneous or visceral depending on the site of involvement. Our patient was a known case of visceral leishmaniasis (kala-azar) and was undergoing treatment in the form of sodium stibogluconate. Although he had become afebrile, he was pale and had hepatosplenomegaly. The laboratory investigations showed low hemoglobin, platelet count and albumin concentration. He had presented with clinical features suggestive of acute appendicitis. The patient did not mount a febrile response and leucocytosis due to appendicitis probably because of a lack of host defense response which is seen even in treated cases of leishmaniasis. The anesthetic course was uneventful. Patients with leishmaniasis may present for elective or emergent surgery unrelated to leishmaniasis or as a result of complications due to the disease such as hypersplenism. The sheer size of the spleen in leishmaniasis makes it more prone to blunt abdominal trauma necessitating splenectomy. Splenectomy may be required sometimes following uncontrolled hemorrhage from the spleen after splenic biopsy. The potential hematological, pharmacological and clinical complications which may influence the anesthetic management should be kept in mind while managing such cases.

Established visceral leishmaniasis is characterized mainly by the failure of cell-mediated immunity, hypoalbuminemic malnutrition and hematological abnormalities. ${ }^{3}$ Pathophysiological changes complicating anesthetic management may be due to the disease itself, secondary to the coexisting infections or the medical treatment. The features of visceral leishmaniasis that may influence the anesthetic course are chiefly the hematologic changes and hypoalbuminemic malnutrition. In advanced disease, the abnormal laboratory findings include pancytopenia- anemia, leukopenia (neutropenia, marked eosinopenia, relative lymphocytosis and monocytosis), and thrombocytopenia- as 
well as hypergammaglobinemia and hypoalbuminemia. ${ }^{1}$ Anemia is the result of shortened red cell survival with destruction of cells in the spleen, along with splenic pooling and sequestration (hypersplenism) as well as marrow infiltration with the parasite. A mild degree of ineffective erythropoiesis contributes to the anemia. The combination of low hemoglobin and a deranged coagulation due to thrombocytopenia poses a big challenge and warrants adequate provision of blood components since transfusion may be required perioperatively. Drugs affecting platelet function and coagulation such as aspirin, nonsteroidal anti-inflammatory and coumadin should be used with caution. A low plasma albumin concentration may adversely influence the pharmacokinetics of agents that are highly protein bound e.g., digoxin, non-steroidal antiinflammatory drugs, phenytoin, benzodiazepines, opioids and thiopental. ${ }^{4}$

A general suppression of cell-mediated immune response followed by leucopenia and hypoalbuminemic malnutrition makes the patient susceptible to secondary infections like pneumonia and tuberculosis, which may complicate the perioperative anesthetic management of such patients. Visceral leishmaniasis may appear in immunosuppressed patients, for example after renal transplantation or as a coinfection with HIV. ${ }^{3}$ Lately it has become an important opportunistic infection among persons infected with HIV in geographic areas where both infections are endemic. ${ }^{1}$

Chemotherapy is the mainstay of management of leishmaniasis and all patients undergoing treatment should be screened for possible adverse effects of these drugs before anesthesia. Pentavalent antimonials such as sodium stibogluconate and meglumine antimoniate remain the drug of choice for visceral leishmaniasis. Antimony toxicity may manifest as chemical pancreatitis, raised hepatic enzymes or low hemoglobin. ${ }^{1}$ The electrocardiogram develops $\mathrm{T}$-wave changes and occasionally prolongation of corrected QT interval, which may herald development of a serious arrhythmia. ${ }^{3}$ The traditional alternatives to antimony are amphotericin $\mathrm{B}$ and pentamidine. Amphotericin B may be associated with side effects such as fever, chills, hypotension, nephrotoxicity, hypovolemia and anemia, while pentamidine can cause hypotension, hypoglycemia, diabetes and vomiting. ${ }^{1}$

Our patient was from an endemic area and was already receiving treatment for kala-azar. Fortunately, he had to undergo a relatively minor procedure where major blood loss was not anticipated. Although he did not suffer from any coexisting medical complication, the hemoglobin level and the platelet count did evoke concern. On the second postoperative day the hemo- globin level was $6.0 \mathrm{~g} \cdot \mathrm{dL}^{-1}$, platelet count $75 \times 10^{9} \cdot \mathrm{L}^{-1}$ and serum albumin concentration was $2.0 \mathrm{~g} \cdot \mathrm{dL}^{-1}$. Two units of fresh whole blood were transfused postoperatively on day two and day four to bring up the hemoglobin level until hemopoeisis recovered. The patient was discharged on the seventh postoperative day.

The possibility of leishmaniasis should be kept in mind in a patient from an endemic area, or if there is a history of a visit to such an area within the last few years, as the incubation period may extend up to two years. The classical fever spikes twice daily, usually without rigor. Europeans and Americans who have acquired the disease while visiting an endemic area more commonly experience an abrupt onset, with high fever and rapid progression of illness with toxemia, weakness, dyspnea, and acute anemia. ${ }^{3}$ The investigation protocol includes complete blood count, blood sugar, blood urea nitrogen, serum creatinine, serum sodium and potassium, serum proteins, coagulation profile, electrocardiogram, chest $x$-ray and tests for HIV. There are no reports on the safety of anesthetic agents and techniques that can be recommended for use in patients with leishmaniasis in the literature and the agents used by us appeared to be safe and effective. Drugs with altered pharmacology in this condition should be used with caution. Regional anesthesia, particularly neuraxial blockade should be considered judiciously in these patients in the presence of coagulopathy induced by thrombocytopenia and liver dysfunction.

A high index of suspicion, a thorough clinical examination and a search for coexisting infection followed by appropriate investigations will limit adverse outcomes in patients with leishmaniasis.

\section{References}

1 Herwaldt BL. Leishmaniasis. In: Fauci AS, Braunwald E, Isselbacher KJ, et al. (Eds.). Harrison's Principles of Internal Medicine, $14^{\text {th }} \mathrm{ed}$. Singapore: MacGraw-Hill, 1998: 1189-93.

2 Park K. Communicable diseases. In: Park K (Ed.). Textbook of Preventive and Social Medicine, $15^{\mathrm{th}}$ ed. Jabalpur: Banarsidas Bhanot, 1997: 232-5.

3 Bryceson ADM. Leishmaniasis. In: Weatherall DJ, Ledingham JGG, Warrell DA, (Eds.). Oxford Textbook of Medicine, $3^{\text {rd }}$ ed. New York: Oxford University Press Inc., 1996: 899-907.

4 Hudson RJ. Basic principles of clinical pharmacology. In: Barash PG, Cullen BF, Stoelting RK (Eds.). Clinical Anesthesia, $3^{\text {rd }}$ ed. Philadelphia: LippincottRaven, 1996: 221-42. 